\title{
Comparison of Career Expectation between Nursing Freshman and Interns
}

\author{
Ni Putu Wulan Purnama Sari \\ Widya Mandala Catholic University Surabaya \\ wulanpurnama@ukwms.ac.id
}

\begin{abstract}
Abstrak
The growing shortage of nurses is a global issue nowadays. The expectation of student nurses towards their future career as a practical nurse should be carefully considered, especially in the millennial generation. This study aimed to compare and analyze the differences in career expectations between nursing first-year students and interns. This cross-sectional study involved 110 and 66 nursing freshmen and interns, respectively $(n=176)$ in two private nursing colleges in the middle part of Indonesia, both institutions were " $B$ " accredited. Career expectations questionnaire was used in data collection. Descriptive statistics and the MannWhitney $U$ test were used for analyzing the data $(\alpha<.05)$. Results showed that nursing interns had higher career expectations than the freshmen (Mean: 77.24 vs. 7I.84); interns had high expectations, while first-year students had enough expectations. There was a significant difference found between groups $(p=.003)$, which influenced by promotion $(p=.00 \mathrm{I})$, leisure time $(p=.015)$, work-life balance $(p=.030)$, business opportunity $(p=.028)$, organization membership $(p=.004)$, and public recognition $(p=.038)$. Career expectation differs significantly between nursing first-year students and interns.
\end{abstract}

Keywords: career, career expectation, nursing, student nurse

Received 24 May 2019/Accepted 25 November 2019 (J)EHCP All rights reserved

\section{Introduction}

The decline in the number of nurses that occur today and continues to occur in the last few decades in various countries has become a global problem (WHO, 2006). Previous studies have shown that despite the fact that there is a declining trend in the number of nurses in various parts of the world, it turns out that not many millennials are interested in the nursing profession (Diomidous, 2012). The growth and resilience of the nursing profession depend on the ability to recruit and maintain the next generation of professional nurses (Price, 20II). Understanding millennial generation career choices is a critical component of nurse recruitment and retention strategies (Bloomberg, 20II; Price, 20II). Some criteria that are often used by student nurse before choosing to be a practical nurse as a career decision include: I) feeling happy to help sick people, 2) being a health professional, 3) easiness to get a job, 4) suitable with personality type, 5) important profession for the 
community, 6) shaping the nursing profession, 7) getting a high salary, 8) supported by family and friends, and 9) various health problems in the family (Diomidous, 20I2).

Career selection is one of the most important decisions an individual makes in his life. Career choice is seen as a core task of the stages of development of late adolescents in the process of building self-identity (Kunnen, 2013). A career that has been chosen has a major contribution to the lives of individuals and can be at the core of one's basic values and life goals. Today the majority of all prospective employees have high career expectations, especially in terms of personal learning and development, skills development, challenging work assignments, work variations, and strong leadership (n-gen Generational Index Report, 2009). A simple slope test revealed that both high and low career expectations were correlated with the nurses' performance in workplaces with high levels of incivility; job performance was significantly better among new nurses with high career expectations than those with low expectations (Zhang et al., 2018). Career expectations mediated the relationship between workplace incivility and job performance; therefore, low career expectations could not modify high workplace incivility and will be resulted in low working performance in nurses.

Career expectations refer to thoughts that can be achieved, realistic, and career targets that are expected to be obtained by an individual in a career (Armstrong \& Crombie, 2000; in Kong, Wang, \& Fu, 2015). These career expectations will determine the individual's motivation to achieve the intended career, related behavior, education, and career success (Creed, Hood, \& Wong, 2009). Career expectations consist of several dimensions, which include: competition, freedom, management, life balance, organizational membership, expertise, learning, and entrepreneurship (Pemberton, 1997). Factors that influence individuals career expectations include: salary, working conditions, good working atmosphere, understanding leaders, good interpersonal relationships, the desire to join a social group, the possibility to be able to apply the skills and knowledge possessed, career growth rapid, prestige, promotion opportunities, and self-expression (Ciarniene, et al, 2010). Some study results show that career expectations are influenced by individual perspectives, such as personality, hobbies, family background, education level, race, and gender (Kong, Wang, \& Fu, 20I5). Another study towards 184 college students aimed at 
investigating the effects of personality and career decision-making self-efficacy showed that self-efficacy mediated the relationship between extraversion and career choice commitment in White students, while neuroticism and extraversion were related to career choice commitment in students of color (Wang et al., 2006).

There are very few numbers of career expectation studies in nursing students, and even almost none to be conducted in Indonesia based on online publication searching, especially towards the Bachelor of Nursing. For instance, a study towards nearly graduated nursing students in Denmark showed that disharmony between career expectations and the experience of being a nurse might complicate the transition from student to new nursing graduate (Thrysoe et al., 2010). The most recent study towards undergraduate nursing students in their final study semester in Norway showed that career choice to work in the field of geriatric care increases with time and relates to career expectations, such as achieving a leadership position and working part-time (Abrahamse, 2019). A study towards Indonesian diploma nursing students after graduation showed that some students developed wrong expectations and goals in their career planning (Gunawan et al., 2018).

Today there are many career choices that can be offered to nursing graduates, especially for the Bachelor of Nursing. With a more promising reward of promotions from employer agencies, it is not uncommon for nursing graduates to choose other professions, for example: working in a beauty clinic or health insurance companies, being a bank employee, becoming an entrepreneur, lecturer, researcher, personal assistant, and many others. To answer the problem of a nursing shortage, the career expectation of student nurses before deciding to be a practical nurse in the future should be carefully considered.

This study aimed to compare and analyze the differences in career expectations between nursing first-year students and interns. In Indonesia, nursing education at a Bachelor's degree is divided into two phases. The first phase is a 4-years academic degree of nursing, and the second phase is a I-year nurse professional degree, which entirely conducted in clinical settings; therefore, the student nurse in this phase is called "intern." 


\section{Method}

Design

This study utilized a cross-sectional design in which all parameters were measured once in time without any follow-up. Therefore this study presented the point prevalence but unable to show the fluctuation of variables' values over time.

\section{Sample}

There were 110 and 66 nursing freshmen and interns, respectively, in two private nursing colleges in the middle part of Indonesia; both institutions were "B" accredited. Inclusion criteria were at least 16 years old and being an active student in the commencement of even semester, the academic year of 2018/2019. Exclusion criteria were a rejection of filling out the consent form and late submission of the questionnaire. Total sampling was applied, and the sample size of 176 was obtained.

\section{Instrument}

The career expectations questionnaire developed by Pemberton (1997) was used in the data collection process. This instrument consisted of eight domains of career expectation: I) competition (item I,II, 19), 2) freedom (item 2,2I,23), 3) management (item 3,7,I4), 4) life balance (item 4,6,16), 5) organization membership (item 9,12,17), 6) expertise (item $13,20,22$ ), 7) learning (item 5,10,18), and 8) entrepreneurship (item 8,15,24). Likert scale of I to 4 was used to differentiate individual responses ranging from no importance until very important. Three categories were used to differentiate response levels in each item: I) low (total score 24-48), 2) sufficient (total score 49-72), and 3) high (total score 73-96). These categories were made in order to ease data interpretation and presentation only.

\section{Data collection and analysis}

Data were collected from February until March 2019, in both sites. Descriptive statistics and Mann-Whitney $U$ tests were used for analyzing the data $(\alpha<.05)$ because the data was not normally distributed $(p=.048)$. The interval data scale was used in statistical analysis by utilizing the raw score of career expectation. 


\section{Ethical consideration}

Ethical clearance was issued by Faculty of Medicine, Widya Mandala Catholic University Surabaya, Indonesia, with certificate number of 009/WMI2/KEPK/T/2019.

\section{Result}

Most respondents were females aged 18-20 years old and living with parents whose profession was non-health professional. They were mostly introvert, melancholic, and realistic. Initially, most respondents chose nursing majors because of personal preference related to a childhood dream. The most considerable motivator was their parents. Table I below explains the demographic characteristic of the study respondents in detail.

Table I

Demographic Characteristic

\begin{tabular}{|c|c|c|c|c|}
\hline \multirow{2}{*}{ Characteristic } & \multicolumn{2}{|c|}{ Freshmen $(\mathrm{N}=\mid \mathrm{I})$} & \multicolumn{2}{|c|}{ Interns $(\mathrm{N}=66)$} \\
\hline & Frequency & $\%$ & Frequency & $\%$ \\
\hline \multicolumn{5}{|l|}{ I. $\quad$ Age (years old) } \\
\hline a. $16-17$ & 14 & 12.73 & 0 & 0 \\
\hline b. $18-20$ & 90 & 81.82 & I & 1.52 \\
\hline c. $21-23$ & 5 & 4.55 & 58 & 87.88 \\
\hline d. $24-26$ & 0 & 0 & 7 & $|0.6|$ \\
\hline e. $>26$ & I & 0.91 & 0 & 0 \\
\hline \multicolumn{5}{|l|}{ 2. $\quad$ Gender } \\
\hline a. Female & 85 & 77.27 & 49 & 74.24 \\
\hline b. Male & 25 & 22.73 & 17 & 25.76 \\
\hline \multicolumn{5}{|l|}{ 3. House-mate } \\
\hline a. Parents & 59 & 53.64 & 52 & 78.79 \\
\hline b. Sibling & 4 & 3.64 & 2 & 3.03 \\
\hline c. Extended Family & 13 & 11.82 & 6 & 9.09 \\
\hline d. Friends & 30 & 27.27 & 5 & 7.58 \\
\hline e. Alone & 4 & 3.64 & I & 1.52 \\
\hline \multicolumn{5}{|l|}{ 4. Profession of house-mate } \\
\hline a. Nurse & 3 & 2.73 & 4 & 6.06 \\
\hline b. Doctor & 1 & 0.91 & I & 1.52 \\
\hline c. Pharmacist & 1 & 0.91 & 0 & 0 \\
\hline d. Others & 105 & 95.45 & 61 & 92.42 \\
\hline \multicolumn{5}{|l|}{ 5. Nurse is parent's profession } \\
\hline a. Yes, & 6 & 5.45 & 4 & 6.06 \\
\hline b. No & 104 & 94.55 & 62 & 93.94 \\
\hline
\end{tabular}




\begin{tabular}{lcccc}
\hline \multicolumn{1}{l}{} & & & & \\
\hline $\begin{array}{l}\text { 6. General personality } \\
\text { a. Introvert }\end{array}$ & 52 & 47.27 & 41 & 62.12 \\
b. Extrovert & 58 & 52.73 & 25 & 37.88 \\
& & & & \\
\hline 7. Personality type & & & & \\
a. Sanguine & 36 & 32.73 & 10 & 15.15 \\
b. Melancholy & 53 & 48.18 & 41 & 62.12 \\
c. Choleric & 11 & 10.00 & 12 & 18.18 \\
d. Phlegmatic & 10 & 9.09 & 3 & 4.55 \\
\hline 8. Character & & & & \\
a. Realistic & 67 & 60.91 & 53 & 80.30 \\
b. Investigative & 10 & 9.09 & 2 & 3.03 \\
c. Artistic & 9 & 8.18 & 6 & 9.09 \\
d. Social & 17 & 15.45 & 5 & 7.58 \\
e. Entrepreneur & 7 & 6.36 & 0 & 0 \\
\hline 9. Reason for choosing a nursing major & & & & \\
a. Making family proud & 1 & 0.91 & 0 & 0 \\
b. Being able to care the family & 9 & 8.18 & 6 & 9.09 \\
c. Personal dream / preference & 54 & 49.09 & 13 & 19.70 \\
d. Being able to help others & 32 & 29.09 & 14 & 21.21 \\
e. Many job opportunities & 3 & 2.73 & 8 & 12.12 \\
f. Others & 11 & 10.00 & 25 & 37.88 \\
\hline I0. Motivator & & & & \\
a. Parents & 90 & 81.82 & 54 & 81.82 \\
b. Self & 18 & 16.36 & 10 & 15.15 \\
c. Others & 2 & 1.82 & 2 & 3.03 \\
\hline
\end{tabular}

The results of descriptive statistics showed that the Mean of career expectation was higher in nursing interns compared to first-year students, but the data was more varied due to higher SD (Mean: 77.24 vs. 7I.84; SD: 10.7 vs. 9.25). The results of the Mann-Whitney $U$ test showed that there was a significant difference in career expectations found between nursing first-year students and interns $(p=.003)$. This difference existed mainly due to the influence of promotion $(p=.00 \mathrm{I})$, leisure time $(p=.0 \mathrm{I})$, work-life balance $(p=.030)$, business opportunity $(p=.028)$, organization membership $(p=.004)$, and public recognition $(p=.038)$. There were five domains of career expectation affected by those differences, namely: competition, life balance (mostly affected), organization membership, expertise, and entrepreneurship. Table 2 below explains the study results in detail. 
Table 2

Comparison of career expectation between nursing first-year students and interns

\begin{tabular}{|c|c|c|c|c|c|}
\hline \multirow{2}{*}{ Characteristic* } & \multicolumn{2}{|c|}{ Freshmen $(\mathrm{N}=\mid \mathrm{I} 0)$} & \multicolumn{2}{|c|}{ Interns $(\mathrm{N}=66)$} & \multirow[t]{2}{*}{ P-Value } \\
\hline & Frequency & $\%$ & Frequency & $\%$ & \\
\hline \multicolumn{6}{|l|}{ Domain: competition } \\
\hline Item I: promotion & & & & & 0.001 \\
\hline a. No importance & 6 & 5.45 & 0 & 0 & \\
\hline b. Slight importance & 9 & 8.18 & I & 1.52 & \\
\hline c. Some importance & 54 & 49.09 & 25 & 37.88 & \\
\hline \multirow[t]{2}{*}{ d. Very important } & $4 I$ & 37.27 & 40 & 60.61 & \\
\hline & \multicolumn{2}{|c|}{ Mean $=3.18 ; S D=0.80$} & \multicolumn{2}{|c|}{ Mean $=3.59 ; \mathrm{SD}=0.53$} & \\
\hline \multicolumn{6}{|l|}{$\begin{array}{l}\text { Domain: life balance } \\
\text { ltem 4: leisure time }\end{array}$} \\
\hline a. No importance & 5 & 4.54 & 2 & 3.03 & \\
\hline b. Slight importance & 25 & 22.72 & 7 & $10.6 \mid$ & \\
\hline c. Some importance & 44 & 40 & 25 & 37.88 & \\
\hline \multirow[t]{2}{*}{ d. Very important } & 36 & 32.72 & 32 & 48.48 & \\
\hline & \multicolumn{2}{|c|}{ Mean $=3.01 ; S D=0.86$} & \multicolumn{2}{|c|}{ Mean $=3.32 ;$ SD $=0.79$} & \\
\hline \multicolumn{6}{|l|}{ Domain: life balance } \\
\hline Item 6: work-life balance & & & & & 0.030 \\
\hline a. No importance & 3 & 2.73 & 0 & 0 & \\
\hline b. Slight importance & 7 & 6.36 & 4 & 6.06 & \\
\hline c. Some importance & 65 & 59.09 & 30 & 45.45 & \\
\hline \multirow{2}{*}{ d. Very important } & 35 & 31.82 & 32 & 48.48 & \\
\hline & \multicolumn{2}{|c|}{ Mean $=3.20 ; S D=0.67$} & \multicolumn{2}{|c|}{ Mean $=3.42 ; \mathrm{SD}=0.6 \mathrm{I}$} & \\
\hline \multicolumn{5}{|l|}{$\begin{array}{l}\text { Domain: entrepreneurship } \\
\text { Item 8: business opportunity }\end{array}$} & 0.028 \\
\hline a. No importance & 2 & 1.82 & I & 1.52 & \\
\hline b. Slight importance & 12 & 10.91 & 5 & 7.58 & \\
\hline c. Some importance & 59 & 53.64 & 26 & 39.39 & \\
\hline \multirow[t]{2}{*}{ d. Very important } & 37 & 33.64 & 34 & 51.52 & \\
\hline & \multicolumn{2}{|c|}{ Mean $=3.19 ;$ SD $=0.70$} & \multicolumn{2}{|c|}{ Mean $=3.4 \mathrm{I} ; \mathrm{SD}=0.70$} & \\
\hline \multicolumn{5}{|l|}{$\begin{array}{l}\text { Domain: organization membership } \\
\text { Item 12: organization membership }\end{array}$} & 0.004 \\
\hline a. No importance & 2 & 1.82 & 0 & 0 & \\
\hline b. Slight importance & 28 & 25.45 & 7 & $10.6 \mid$ & \\
\hline c. Some importance & 70 & 63.64 & 47 & 71.21 & \\
\hline \multirow[t]{2}{*}{ d. Very important } & 10 & 9.09 & 12 & 18.18 & \\
\hline & \multicolumn{2}{|c|}{ Mean $=2.80 ;$ SD $=0.62$} & Mean $=3$ & $\mathrm{D}=0.70$ & \\
\hline Domain: expertise & & & & & \\
\hline Item I3: public recognition & & & & & 0.038 \\
\hline a. No importance & 15 & 13.64 & 3 & 4.55 & \\
\hline b. Slight importance & 17 & 15.45 & 5 & 7.58 & \\
\hline c. Some importance & 42 & 38.18 & 31 & 46.97 & \\
\hline d. Very important & 36 & 32.73 & 27 & 40.91 & \\
\hline & Mean $=2.90$ & $=1.01$ & Mean $=3$ & $\mathrm{D}=0.79$ & \\
\hline Overall career expectation & & & & & 0.003 \\
\hline a. Low & I & 0.91 & 0 & 0 & \\
\hline b. Sufficient & 61 & 55.45 & 22 & 33.33 & \\
\hline c. High & 48 & 43.64 & 44 & 66.67 & \\
\hline & Mean $=71.84$ & $=9.25$ & Mean $=77$ & $S D=10.7$ & \\
\hline
\end{tabular}

* Category was made to ease the data presentation, and not for statistical analysis purposes. 


\section{Discussion}

Results showed that there was a significant difference in career expectations between firstyear students and interns in nursing students. This difference existed mainly due to the influence of promotion, leisure time, work-life balance, business opportunity, organization membership, and public recognition. The majority of first-year students had sufficient career expectations (55.45\%), while the majority of interns had high career expectations $(66.67 \%)$. The mean value of career expectation is higher in interns compared to freshmen (77.24 vs. 7I.84), even though the sample size of first-year students is doubled than the interns in this study. A study towards 429 university students showed that the grade difference influenced new students more than the senior student, especially for the type of career in the health sector with $1.77 \%$ vs. I.37\% of influence (Lockridge, 2000 ).

In general, we can see a decline in career expectations in the millennial generation, because the results of this study showed higher career expectations in interns compared to first-year students. A study of De Hauw \& De Vos (2010) towards I,6/2 college graduates showed that the decline in career expectation was due to a decrease in the level of optimism. They stated that career expectations, especially in the millennial generation, are significantly influenced by personal variables, career, and optimism. In the period of recession, the millennial generation has lowered their career expectations due to the influence of the balance between life and work, as well as the social atmosphere. However, their expectations of work assignments, training opportunities, career development, and salary/benefits/ rewards remain high.

Regarding personal variables, the personality of first-year students is mostly extrovert (52.73\%), while the interns are mostly introvert (62.12\%). However, the type of personality and character are relatively the same, namely melancholy (total: $53.41 \%$ ) and realistic (total: 68.18\%). No specific study has been found on human personality and its influence on career expectations, especially in the millennials who study in the nursing major. Nevertheless, a study by Lounsburry et al. (2007) towards 1,059 workers in the field of information technology showed that introverts were more suitable to work in this field. The personality traits studied include assertiveness, emotional endurance, extraversion / social ability, openness, teamwork, customer service orientation, optimism, and work ethic. Their study 
results indicate that individuals who have 3 or 4 types of personality traits above, his career expectations are influenced by his personality with $17 \%$ and $25 \%$ influences, respectively. There is a possibility that personality traits influence nursing students in choosing their major.

There are psychological limitations in both men and women if they decide on a career as a nurse. Most study respondents are females (total: 76.14\%). A study in the UK towards firstyear nursing students showed that there are certain areas of specialization that are popular among male and female students that relate to their perceptions of the nurse profession that is appropriate for their sex (Muldoon \& Reilly, 2003). There is an influence of gender and role identity according to sex, which also influences the choice of the specialization nursing field to be pursued if a student has chosen a career as a practical nurse.

Gender explains the large variance in one's career expectation, regardless of the field of science, academic achievement, or career goals (Schweitzer et al., 20ll). There was no specific study in nursing students about the differences in career expectations between male and female students. But, a study towards 919 physiotherapy students showed that there were differences in career expectations between male and female students, where male students expressed more desire to have private practices, become lecturers, publish articles in professional journals, and desire to earn more salaries high in the first year of work (Johanson, 2007). Another study towards 36 students majoring in construction showed that career expectations differed significantly between men and women, where after becoming a professional, it turned out that women were more positive and optimistic in trusting their abilities and developing their careers than men (Bennett et al., 1999).

A secondary study using Educational Longitudinal Study data (ELS, 2002) in the United States showed that family backgrounds could predict career expectations and success in student life where the influence between these variables is mediated by academic self-efficacy (Kim, 2014). Most respondents in this study live with parents (total: 63.07\%) whose profession is mostly non-health professional (total: $94.32 \%$ ), but parents are proved to be the most considerable motivator for the students (total: $81.82 \%$ ) to pursue the higher education in the nursing major. Optimism in a career comes from the support of parents and teachers in 
the initial phase, and self-efficacy related to career decision making in the final phase (Garcia et al., 2015); these variables were not explicitly examined in this study.

Career growth is related to the promotion. Promotion opportunities are one aspect that causes a significant difference in career expectations between first-year students and interns. The most important career aspiration factor for generation $Y$ is promotion (Holbeche, 2003; in Maxwell et al., 2010). The belief influences fast career growth in self-efficacy towards career development, which influenced by parents' expectations, parent-child relationships, and cultural values (Sandhu, 20I4).

Time to travel or relax "me time," often referred to as leisure time, refers to the opportunity for free time, vacation, and leisure; included in social rewards related to interpersonal relationships in the workplace (Twenge et al., 2010). Leisure time is one aspect that causes a significant difference in career expectations between first-year students and interns. A study of 16,507 workers consisting of baby boomers, $X$, and $Y$ generations showed that the value of leisure time continued to increase from generation to generation, but the centrality of work actually declined; generation $Y$ does not like altruistic work (e.g., helping other people, social work) and considers social values - intrinsically less important than the previous generation (Twenge, 2010).

The balance between work and life is a life experience that always changes and depends on several factors. Flexibility is needed to balance a person's multiple roles without seeing the level of his career. There is a direct relationship between economic status and human resources with a person's ability to balance work and life (Williams, 20I5). The balance between work and life is one aspect that causes a significant difference in career expectations between first-year students and interns. A study of 20 male African workers who were citizens of the United States showed that the majority of individuals experienced a balance between work and life, but participants assumed that it was very difficult or impossible to achieve this balance even though it was imperative (Williams, 2015). Another study of 85 millennial generation workers in America showed that there was no significant relationship between the use of technology-based tools during working hours (e.g., 
computers, cell-phones, faxes) with a balance between work and life and worker satisfaction with that balance (Stokes, 2019).

The opportunity to open a new business is one aspect that causes a significant difference in career expectations between freshmen and interns. The ability of individuals to recognize opportunities for entrepreneurship is a factor that influences their decision to choose a career as an entrepreneur (Asante \& Affum-Osei, 2019). The results showed that only one freshman chose a career as an entrepreneur $(0.91 \%)$, while none interns chose this career. This indicates that the millennial generation is better able to see opportunities for entrepreneurship than their seniors. The results of other studies of 376 final-year students at the University of Granada, Spain, showed that cognitive aspects relate to coping and adaptive exploration mediate the relationship between career goals and the level/strength of decisions for a career as an entrepreneur (Perez-Lopez, 2019).

Organization membership is one aspect that causes a significant difference in career expectations between first-year students and interns. There are no specific studies related to this aspect in the field of career expectation, especially in nursing students. However, a study in the Netherlands towards 747 professional employees showed that their pro-activity was related to supervisory support at various levels of creativity from the manager, such as problem identification, information-seeking behavior, and the emergence of new ideas, where pro-activity positively correlated with problem identification and information retrieval, while supervisory support is negatively correlated with information-seeking behavior and the emergence of new ideas (Caniels, 2019).

Public recognition of individual expertise is one aspect that causes significant differences in career expectations between first-year students and interns. There are no specific studies related to this aspect in the field of career expectations, especially in nursing students. However, a study of millennial generation workers showed that millennials attach importance to affiliation, empowerment, bonuses, and public recognition rather than other intrinsic or extrinsic motivators, and this motivator can cause higher employee retention, increased motivation, and organizational social behavior; women position themselves equally with men, especially in terms of work achievement and independence (Sledge, 2016). 
This study also has some limitations. The cross-sectional design utilized in this study has made the inability to identify the changing value of career expectations over time due to the changes in factors that influenced this variable. Other than that, the questionnaire which used in data collection process was failed to address local issue e.g., specific culture related to ethnic and custom affecting parenting and mindset in the children, so that career expectation in nursing students assessed by this instrument may not give the whole picture of this variable.

\section{Conclusion}

These study results indicate that the career expectation of interns is higher than first-year students, and there is a significant difference between groups. Various factors influence this difference, such as promotion, leisure time, work-life balance, business opportunity, organization membership, and public recognition. However, there is a tendency that the older the age then, the higher the career expectation. Nowadays, the millennial generation puts forward the aspects of reward in the form of promotion, leisure time, business opportunity, and public recognition of expertise or work performance. Nursing implications in the field of nursing education need to address the issue of career expectation since the very beginning of college life in first-year nursing students, and the maturation or modifications need to be done in the on-going teaching-learning process by counseling method through the strengthening role of an academic advisor and parents' involvement. Further study may elaborate more on the factors influencing career expectations, specifically in nursing first-year students and interns, for allowing variable modification important for increasing working performance in future nurses.

\section{Acknowledgment}

This study was funded and supported for publication by the Faculty of Nursing, Widya Mandala Catholic University Surabaya. 


\section{References}

Abrahamsen, B. (2019). A longitudinal study of nurses' career choices: the importance of career expectations on employment in the care of older people. J Adv Nurs., 75(2), 348356.

Asante, E. A., \& Affum-Osei, E. (2019). Entrepreneurship as a career choice: the impact of locus of control on aspiring entrepreneurs' opportunity recognition. Journal of Business Research, 98, 227-235.

Bennett, J. F., Davidson, M. J., \& Galeand, A. W. (1999). Women in construction: a comparative investigation into the expectations and experiences of female and male construction undergraduates and employees. Women in Management Review, I4(7), 273291.

Ciarniene, R., Kumpikaite, V., \& Vienazindiene, M. (2010). Expectations and Job Satisfaction: Theoretical and Empirical Approach. Retrieved from:

http://leidykla.vgtu.It/conferences/BUS_AND_MANA_2010/Enterprise_Management/09 78-0984_Ciarniene_Kumpikaite_Vienazindiene.pdf

Creed, P., Hood, M., \& Wong, O. (2009). Career decision-making, career barriers, and occupational aspirations in Chinese adolescents. International Journal for Educational and Vocational Guidance, 9(3), 189-203.

De Hauw, S., \& De Vos, A. (2010). Millennials' career perspective and psychological contract expectations: does the recession lead to lowered expectations?. Journal of Business and Psychology, 25(2), 293-302.

Diomidous, M., Mpizopoulou, Z., Kalokairinou, A., Mprokalaki, I., Zikos, D., \& Katostaras, T. (20I2). Descriptive Study of Nursing Students' Motives to Choose Nursing as a Career. Retrieved from: journal-ene.gr/wp-content/uploads/2013/07/descriptive_study_nursing_students.pdf

Garcia, P. R. J. M., Restubog, S. L. D., Bordia, P., Bordia, S., \& Roxas, R. E. O. (20I5). Career optimism: the roles of contextual support and career decision-making self-efficacy, Journal of Vocational Behavior, 88, 10-18.

Gunawan, J., Aungsuroch, Y., Sukarna, A., \& Wahab, N. (2018). Nursing students plan after graduation. J Educ Health Promot., 7(I), PMC 579I428.

Johanson, M. A. (2007). Sex differences in career expectations of physical therapist students. Phys Ther., 87, II99-1211.

Kim, M. (20I4). Family background, students' academic self-efficacy, and students' career and life success expectations. Int J Adv Counselling, 36, 395-407. 
Kong, H., Wang, S., \& Fu, X. (20I5). Meeting career expectation: can it enhance job satisfaction of Generation $Y$ ? International Journal of Contemporary Hospitality Management, 147-168.

Kunnen, E. S. (2013). The Effects of Career Choice Guidance on Identity Development. Retrieved from: http://dx.doi.org/10.1I55/2013/9017/8

Lockridge, E. J. K. (2000). Career aspirations and expectations of selected Texas high school students as they relate to demographic characteristics and occupational projections. Dissertation. ProQuest Dissertations Publishing, 9980180.

Lounsbury, J. W., Moffitt, L., Gibson L. W., Drost, A. W., \& Stevens, M. (2007). An investigation of personality traits in relation to job and career satisfaction of information technology professionals. Journal of Information Technology, 22, 174-183.

Maxwell, G. A., Ogden, S. M., \& Broadbridge, A. (2010). Generation Y's career expectations and aspirations: engagement in the hospitality industry. Journal of Hospitality and Tourism Management, I7(I), 53-6I.

Muldoon, O. T., \& Reilly, J. (2003). Career choice in nursing students: gendered constructs as psychological barriers. JAN, 43(I), 93-100.

n-gen Generational Index Report. (2009). Career Expectations. Retrieved from: www.ngenperformance.com/wp-content/uploads/2010/08/Career-Expectations.pdf

Pemberton, C. (1997). Career Expectations Questionnaire. Retrieved from: www.birmingham.ac.uk/generic/decide/documents/career-expectations.pdf .

Perez-Lopez, M. C., Gonzalez-Lopez, M. J., \& Rodriguez-Ariza, L. (2019). Applying the social cognitive model of career self-management to the entrepreneurial career decision: the role of exploratory and coping adaptive behaviors. Journal of Vocational Behavior, I / 2, 255-269.

Price, S. L. (20II). The Experience of Choosing Nursing as a Career: Narratives from Millenial Nurses. Retrieved from: https://tspace.library.utoronto.ca/bitstream/I807/3I905/3/Price_Sheri_L_20 I I I I_PhD_ thesis.pdf.

Sandhu, G. (2014). The influence of family and cultural values on the career development of Asian Americans. Dissertation. ProQuest Dissertations Publishing, 10034392. 
Schweitzer, L., Ng, E., Lyons, S., \& Kuron, L. (20II). Exploring the career pipeline: gender differences in pre-career expectations. Relations Industrielles, 66(3), 422-444.

Sledge, J. C. (2016). Motivation and retention of Generation Y employees in the workplace. Dissertation. ProQuest Dissertations Publishing, 10297504.

Stokes, Y. (2019). Technology tool use and work/life balance among millennial workers: a correlational study. Dissertation. ProQuest Dissertations Publishing, I 3426340.

Thrysoe, L., Hounsgaard, L., \& Lis, W. (2010). Expectations of becoming a nurse and experiences of being a nurse. Vård I Norden, I0I(3), I5-19.

Wang, N., Jome, L. M., Haase, R. F., \& Bruch, M. A. (2006). The role of personality and career decision-making self-efficacy in the career choice commitment of college students. Journal of Career Assessment, I4(3), 3 I 2-332.

Williams, M. D. C. (20I5). African American men in organizations: a critical interpretation of work-life balance through role determination and organizational support. Dissertation. ProQuest Dissertations Publishing, I00087I0.

World Health Organization (WHO). (2006). Working Together for Health: The World Health Report 2006. Geneva: WHO.

Zhang, S., Ma, C., Meng, D., Shi, Y., Xie, F., Wang, J., Dong, X., Liu, J., Cang, S., \& Sun, T. (20/8). Impact of workplace incivility in hospitals on the workability, career expectations, and job performance OF Chinese nurses: a cross-sectional survey. BMJ Open, 8, e021874. 